\title{
Comparative Study of Flood Calculation Approaches, a Case Study of East Rapti River Basin, Nepal
}

Krishna Prasad Rijal

\begin{abstract}
Various approaches to high flood calculation have been used to inform the design of hydraulic structures and flood protection works in Nepal. To assess potential flood volumes, a variety of methods and calculations are employed and the highest figure is adopted as correct so as to err on the side of safety. This approach, while safe, can result in excessively uneconomic design. As well, this approach erodes the designer's confidence in the process to determine the potential flood volume and perpetuates such sub-optimal approaches. Through the case study of East Rapti River, this paper tries to shed light on various ungauged basin approaches of flood prediction currently in practice. It also compares the relative performance of those approaches using statistical methods and observed data. From the study, Jha PCJ method (1996) yielded a comparable result with the gauged basin methods. A remarkably notable fact obtained is that all the ungauged basin methods except rational method underestimated the flood discharge as compared to that obtained from the frequency analysis based on measured data sets. Overall, our study concludes that flood forecasting on ungauged basins cannot be recommended because a number of assumptions and personal judgments influence each of the prediction methods. Therefore, a more radical shift to basin specific intensive research is desirable.
\end{abstract}

Key words: Flood control, flood, comparative study, ungauged basin, Nepal

\section{Introduction}

Zlood discharge calculation is a prominent task for

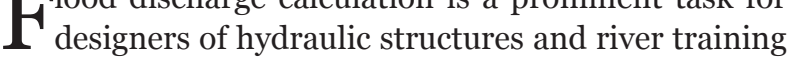
works. In Nepal, this task is made more difficult because hydrological information isn't available for many areas of the country, and where data is available, sufficient time series cannot be obtained. The problem is further complicated because the hydrology of mountainous areas is itself not very well developed and the combination of extremely high altitudes, steep slopes and intense seasonal (monsoonal) precipitation, limits and even precludes, the transfer of hydrological techniques, principles, and models developed in the temperate regions of Europe and America to the Hindu Kush Himalays (Chalise 1994). Lack of data sharing among researchers also hampers potential gains in flood structure design. The legacies of such anomalies have resulted water induced disasters and have damaged a myriad of infrastructures such as buildings, roads, bridges and barrages in this country. The glaring examples are the breaches of headworks of Mohana Irrigation System, Kankai Irrigation System and Bagmati Irrigation System in irrigation sector and breach of road sections and bridges on Prithvi Highway in 1993 in the road sector.

To date, comprehensive national guidelines and codes have not been developed for flood forecasting in this country. Water resource professionals have been using their experience and personal judgment to select flood forecasting methods to inform the design of flood control structures. This grossly inadequate knowledge of hydrological processes and weak understanding of the symbiotic relationship between governing hydrological parameters and design have led to construction of flood barriers that may not be appropriate. Long-term research programs within a regional framework, on hydrological responses to climate can provide the best impetus to intensify research in these fields at the national level while promoting regional cooperation (Chalise 1994).

Surface run-off is a function of a number of parameters including rainfall, land cover, land use, topography, soil type, and climatic conditions. In a mountainous country like Nepal, these parameters vary generally in spatial and temporal dimensions. Mountain topography and rain shadow effects further complicate precipitation patterns and even adjacent watersheds can be widely different in terms of climate and hydrological regimes (Chalise 1994). Due to these factors, a direct physics-based approach to flood calculation is very complex and impracticable. While these simpler practices are adequate for regions of Europe and the Americas, in Nepal these approaches do not properly account for its diverse hydroclimatic zones. This paper will shed some light on flood forecasting using the East Rapti River basin of Nepal as a case study on which it compares some flood calculation approaches that have been widely used in Nepal.

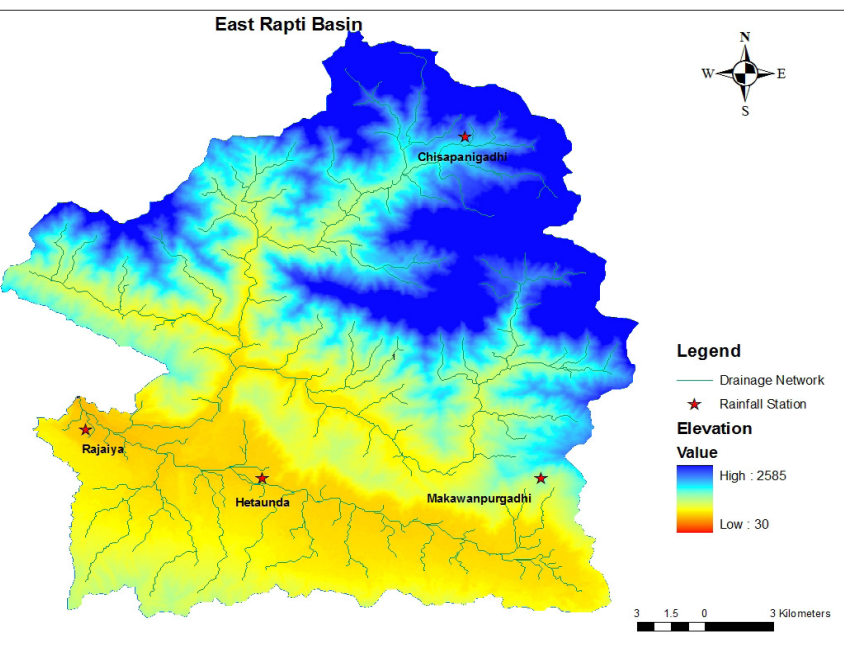

Figure 1: East Rapti River Basin, Catchment area at Rajaiya. 


\section{Study Area}

The East Rapti River basin is a sub-basin of Narayani River system. It is located in the central development region of the country and passes through Makawanpur and Chitwan districts. The basin extends from latitude $27^{\circ} 21^{\prime} 23^{\prime \prime} \mathrm{N}$ to $27^{\circ} 47^{\prime}$ oo" $\mathrm{N}$ and longitude $84^{\circ}$ o8' $43^{\prime \prime E}$ to $85^{\circ} 11^{\prime} 57^{\prime \prime} \mathrm{E}$. About $56 \%$ of the basin area lies within the Chitwan district while $44 \%$ extends into the Makawanpur district. The East Rapti River originates at Chisapanigadhi of Makawanpur district and merges with Narayani River at Meghauli Village Development Committee (VDC) of Chitwan district. The total length of the river is $122 \mathrm{~km}$ and total catchment area is $3109 \mathrm{~km}^{2}$ (Shilpakar 2003).

This study covers the catchment area of East Rapti River lying upstream of the hydrological station located at Rajaiya $(85.07 \mathrm{E}, 27.48 \mathrm{~N})$ of Makawanpur district of Nepal as shown in Figure 1. The catchment area of this portion is $471 \mathrm{~km}^{2}$. This study area encompasses four rain gauge stations (Station Index: 904, 906, 919, 925) as shown in Figure 1. This study have employed the rainfall data from these four rain gauge stations and hydrological data from the hydrological station index number 460 .

\section{Materials and Methods}

Typically, there are two methods of flood calculation employed and selected based on the availability of hydrological data. If time series discharge data are available (gauged basins), frequency analysis is the preferred method for computing design peak flood discharge. Otherwise, rational or empirical formula are used (un-gauged basins).

\section{Gauged basins}

\section{Gumbel's method}

This is one of the most widely used extreme value prediction methods. Following key formula were used for this study.

$$
\begin{array}{rc}
X_{T}=\bar{X}+K \sigma_{n-1} & \sigma_{n-1=\sqrt{\frac{\sum(X-\bar{X})^{2}}{N-1}}} \\
\text { Where, } \quad K=\frac{y_{t}-y_{n}}{S n} & y_{t}=-\left[\ln \ln \left(\frac{T}{T-1}\right)\right]
\end{array}
$$

$\mathrm{X}_{\mathrm{T}}=$ Value of variate $\mathrm{x}$ at return period $\mathrm{T}$

$\overline{\mathrm{X}}^{\mathrm{T}}=$ Mean of variate $\mathrm{X}$

$\mathrm{K}=$ frequency factor

$\sigma_{\mathrm{n}-1}=$ Standard deviation of sample size $\mathrm{N}$

$\mathrm{Y}_{\mathrm{t}} \quad=$ Reduced variate

$\mathrm{Y}_{\mathrm{n}}{ }^{\mathrm{t}}=$ Reduced mean

$\mathrm{S}_{\mathrm{n}}^{\mathrm{n}} \quad=$ Reduced standard deviation

\section{LOG-Pearson Type III Distribution}

Similar to Gumbel's method, this is also widely used extreme value prediction method. The following calculations were used for the analysis in this study:

$$
\begin{array}{cl}
Z=\log x & \sigma_{z}=\sqrt{\frac{\sum(Z-\bar{Z})^{2}}{(N-1)}} \\
Z_{T}=\bar{Z}+K_{Z} \sigma_{z} & C_{s}=\frac{N \sum(z-\bar{z})^{3}}{(N-1)(N-2)\left(\sigma_{Z}\right)^{3}}
\end{array}
$$

Where,

$\mathrm{X}=$ variate of random hydrologic series

$\mathrm{Z}_{\mathrm{T}}=$ Transformed series value for return period $\mathrm{T}$

$\mathrm{K}_{\mathrm{z}}=$ frequency factor $\mathrm{f}\left(\mathrm{C}_{\mathrm{s}}, \mathrm{T}\right)$

$\sigma_{\mathrm{z}}=$ Standard deviation of $\mathrm{Z}$ variate sample.

\section{Ungauged basins}

\section{Rational method}

This is a widely used method for peak flow calculation for small areas. However, in practice, this method has been widely used in Nepal for even larger areas as well. Following formula were used in this study:

Where, $Q_{p}=\frac{C\left(I_{(t c, p)}\right) A}{360}$

$\mathrm{Q}_{\mathrm{p}}=$ Peak flood discharge

$\mathrm{C}=$ Runoff coefficient

$\mathrm{I}_{\mathrm{tc}}, \mathrm{p}=$ Intensity of rainfall at time of concentration $\mathrm{t}_{\mathrm{c}}$ $(\mathrm{mm} / \mathrm{hr})$, and probability of exceedence $\mathrm{P}$

$\mathrm{A}=$ Catchment Area in hectare.

Though Rajaiya station measures runoff of a catchment area of medium size, this method was used in this study for comparative purposes as in usual practice. A weighted value of runoff coefficient $c$ was adopted as per land use of the catchment area as depicted in table 1 .

\begin{tabular}{|c|c|c|c|}
\hline $\begin{array}{c}\text { S. } \\
\text { No. }\end{array}$ & Land use & Area (km2) & $\begin{array}{c}\text { Runoff coef- } \\
\text { ficient used }\end{array}$ \\
\hline 1 & Agriculture & 181.00 & .20 \\
\hline 2 & Forest & 225.00 & .30 \\
\hline 3 & Rock/Meadow & 65.00 & .80 \\
\hline \multicolumn{2}{|c|}{ Data source of Land use and Area: Sharma and Adhakari (2004) } \\
\hline
\end{tabular}

Table 1: Runoff coefficient of East Rapti River Basin

Intensity of rainfall $\mathrm{I}_{(\mathrm{tc}, \mathrm{p})}$ was calculated using time of concentration $\left(t_{c}\right)$ as suggested by the Kirpich equation :

$$
\mathrm{t}_{\mathrm{c}}=0.01947 L^{0.77} \mathrm{~S}^{-0.385}
$$

The length of catchment (L) is $37 \mathrm{~km}$ and slope of catchment (S) is 13 percent. Fifty-year return period rainfall was calculated at all rainfall stations within the catchment area of Rajaiya station. Then using the Thiessen polygon method, fifty-year rainfall of the catchment area was computed.

Intensity of rainfall was calculated using following equation:

$$
I_{t c}=\frac{R}{24}\left(\frac{24}{t c}\right)^{\left(\frac{2}{3}\right)}
$$

Where,

$\mathrm{R}=24$ hour rainfall (mm)

\section{SCS Method}

The SCS (Soil Conservation Service) method was 
developed by the USDA (United States Department of Agriculture) Natural Resources Conservation Service. This method is generally used in small catchments. The runoff was estimated using the following formula:

$$
Q=\frac{\left(P-I_{a}\right)^{2}}{P+4 I_{a}}
$$

Where, $Q$ is the runoff in mm, $P$ is the design rainfall in $\mathrm{mm}$ and $I a$ is the initial loss due to infiltration, interception and surface storage.

The initial loss $I a$ is obtained with the use of curve number $(\mathrm{CN})$. The curve number of East Rapti basin adopted as per the land use is depicted in table 2.

\begin{tabular}{|c|c|c|c|c|}
\hline $\begin{array}{c}\text { S. } \\
\text { No. }\end{array}$ & $\begin{array}{c}\text { Land } \\
\text { use }\end{array}$ & $\begin{array}{c}\text { Hydro- } \\
\text { logical } \\
\text { soil class } \\
\text { adopted }\end{array}$ & $\begin{array}{c}\text { CN } \\
\text { Value } \\
\text { used }\end{array}$ & Remarks \\
\hline 1 & $\begin{array}{c}\text { Agricul- } \\
\text { ture }\end{array}$ & B & 76.5 & $\begin{array}{c}\text { Av. Value of row } \\
\text { crops \& Broadcast } \\
\text { crops, slow runoff }\end{array}$ \\
\hline 2 & Forest & B & 60 & $\begin{array}{c}\text { Wood, Moderate } \\
\text { runoff }\end{array}$ \\
\hline 3 & $\begin{array}{c}\text { Rock/ } \\
\text { Meadow }\end{array}$ & B & 85 & $\begin{array}{c}\text { Assumed Gravel, } \\
\text { rock condition }\end{array}$ \\
\hline
\end{tabular}

Table 2: CN Value for East Rapti River Basin

$$
I_{a}=5.08\left(\frac{1000}{C N}-10\right) \mathrm{mm}
$$

\section{WECS/DHM Method}

WECS/DHM (1990) method employs regional prediction methods. It is a modification of WECS (Water and Energy Commission Secretariat) approach of 1982 and has been developed jointly by WECS and DHM (Department of Hydrology and Meteorology) in cooperation with WMO (World Meteorological Organization), WERDP (Water and Energy Resource Development Project, until 1989) and WISP (WECS/NEA Institutional Support Programme) in 1990 (Shrestha et al., 2010). The following equations were used for flood forecasting:

$$
\begin{gathered}
Q_{2}=1.8767\left(A_{3000}\right)^{0.8783} \\
Q_{100}=14.639\left(A_{3000}\right)^{0.7342} \\
Q_{50}=\exp 3\left[\ln Q_{2}+2.054\left(\frac{\ln \left(Q_{100} / Q_{2}\right)}{2.326}\right)\right]
\end{gathered}
$$

Where, $\mathrm{Q}_{2}, \mathrm{Q}_{100}, \mathrm{Q}_{50}$ are 2-, 100- and 50-year return period floods respectively and $\mathrm{A}_{3000}$ is the catchment area under 3000 m elevation.

\section{Sharma and Adhikari Method}

The Sharma and Adhikari (2004) method uses hydrometric data up to 1995 and hence can be considered the updated WECS and DHM method. Following formula were used in this study:

$$
\begin{gathered}
Q_{2}=2.29\left(A_{3000}\right)^{0.86} \\
Q_{100}=20.7\left(A_{3000}\right)^{0.72} \\
Q_{50}=\exp 2\left[\ln Q_{2}+2.054\left(\frac{\ln \left(Q_{100} / Q_{2}\right)}{2.326}\right)\right]
\end{gathered}
$$

\section{Tahal et al. Method}

The Tahal et al. (2002) method uses the index flood method for flood forecasing. Following formula were used following this method:

$$
Q_{T}=Q_{m}(.3838 \ln (T)+.6882)
$$

Where, $Q_{t}$ and $Q_{m}$ are flood flow of return period T and mean flood flow, respectively.

For Narayani Basin:

$$
Q_{m}=5.42\left(A_{3000}\right)^{0.7572}
$$

\section{Modified Dicken's Method}

This method is also widely used in Nepal.

$$
\begin{gathered}
\mathrm{Q}_{\mathrm{f}}=\mathrm{CA}^{3 / 4} \\
C=2.342 \log (0.6 T) \log \left(\frac{1185}{P}\right)+4 \\
P=\frac{100\left(A_{s}+6\right)}{A}
\end{gathered}
$$

Where, $A$ and $A s$ are the total catchment area and snow covered area $\left(\mathrm{km}^{2}\right)$ respectively and $T$ is return period in years.

\section{PCJ Method}

The PCJ method (Jha 1996) calculates design peak flood discharge based on hourly rainfall intensity. This method employs following formula:

$$
\mathrm{Qp}=16.67 \mathrm{a}_{\mathrm{p}} \mathrm{O}_{\mathrm{p}} \Phi \mathrm{Fk}_{\mathrm{f}}+\mathrm{Qs}
$$

Where,

$\mathrm{Q}_{\mathrm{p}} \quad$ = Maximum rainfall design discharge for required exceedence probability (p) in $\mathrm{m}^{3} / \mathrm{sec}$

$a_{p} \quad=$ Maximum rainfall design intensity for required exceedence probability $(\mathrm{p})$ in $\mathrm{mm} / \mathrm{min}$

$\mathrm{a}_{\mathrm{p}}=\mathrm{a}_{\mathrm{hr}} \cdot \mathrm{k}_{\mathrm{t}}$, where, $\mathrm{a}_{\mathrm{hr}}=$ Hourly rainfall intensity for required exceedence probability (p) in $\mathrm{mm} / \mathrm{min}$ at selected rainfall stations $\mathrm{k}_{\mathrm{t}}=$ Reduction coefficient of hourly rainfall intensity (depends on the size of catchment area)

$\mathrm{o}_{\mathrm{p}}=$ Infiltration coefficient of the basin, derived as the function of exceedence probability (p)

$\Phi=$ Areal reduction coefficient of maximum rainfall discharge (depends on the size of catchment)

$\mathrm{F}=$ Catchment area of drainage basin in sq. $\mathrm{km}$.

$\mathrm{k}_{\mathrm{F}}=$ Coefficient for unequal distribution of rainfall in different size of basin, captured by one rain.

$\mathrm{Q}_{\mathrm{S}}=$ Discharge by melting of snow, can be taken as o to $10 \%$ of QP in the absence of data.

\section{Result and Discussion}

\section{Frequency Analysis Methods}

From frequency analysis of 43 year data (from 1963 to 2006) at hydrological station number 460, located at Rajaiya, peak flood at various return periods was calculated using both Gumbel and Log Pearson methods. The results are shown in Table 3. 


\begin{tabular}{|c|c|c|c|l|}
\hline \multirow{2}{*}{$\begin{array}{c}\text { S. } \\
\text { No. }\end{array}$} & $\begin{array}{c}\text { Return } \\
\text { Period } \\
\text { (years) }\end{array}$ & $\begin{array}{c}\text { Gumbel } \\
\text { Method }\end{array}$ & $\begin{array}{c}\text { Log Pearson } \\
\text { III Method }\end{array}$ & Remarks \\
\hline 1 & 2 & 574.62 & 513.73 & \\
\hline 2 & 10 & 1447.55 & 1235.26 & \\
\hline 3 & 25 & 1886.91 & 1736.27 & \\
\hline 4 & $\mathbf{5 0}$ & $\mathbf{2 2 1 2 . 8 4}$ & $\mathbf{2 1 8 2 . 5 6}$ & \\
\hline 5 & 100 & 2536.38 & 2692.32 & \\
\hline 6 & 200 & 2858.73 & 3276.65 & \\
\hline
\end{tabular}

Table 3: Comparison of flood discharge using Gumbel and Log Pearson III methods.

Gumbel and Log Pearson Type III analysis yield comparable results. Comparing time series data over the study period, the highest flood of $3260 \mathrm{~m}^{3} / \mathrm{s}$ that had occurred in 2004 corresponded to 200 year return period flood as per Log Pearson type III method.

This study showed that forecasted flood values for a return period less than 50 years by Gumbel's method were higher than figures arrived at through the Log Pearson Type III method. For longer return periods (> 50 years), Log Pearson showed higher flood values (Figure: 2).

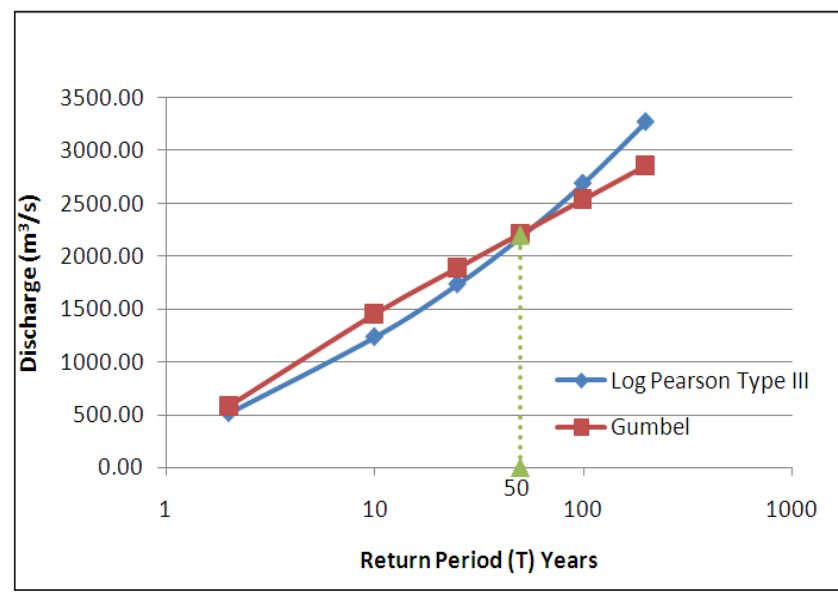

Figure 2: Flood Probability Analysis of East Rapti River

\section{Ungauged Catchment Methods}

Using various flood forecasting methods comprising both rational and empirical data analysis, a fifty-year return period flood was computed. For comparing the results of gauged and ungauged catchment methods of flood forecasting, discharge calculation was based on the Rajaiya station (DHM station No. 460). The result obtained has been presented in Table 4. Figure 3 depicts the graphical representation of those values along with the flood values obtained by Gumbel's method.

The result shows that all these methods except rational method underestimated the flood values at the same return period of 50 years when compared with frequency analysis (gauged basin) methods. However, the PCJ (1996) method yields a comparable result (at a deviation of about 5 percent) with that obtained from gauged basin methods.

\begin{tabular}{|c|l|c|}
\hline S. No. & Flood forecasting methods & $\begin{array}{c}\text { Peak discharge } \\
\left(\mathbf{m}^{\mathbf{3}} \mathbf{/ s}\right) \mathbf{f o r} \mathbf{T}=\mathbf{5 0} \text { yrs }\end{array}$ \\
\hline 1 & Rational method & 3273 \\
\hline 2 & SCS Method & 1634 \\
\hline 3 & WECS/DHM & 1172 \\
\hline 4 & Sharma and Adhikari method & 1488 \\
\hline 5 & Tahal et al. (2002) method & 1254 \\
\hline 6 & Modified dicken's method & 1443 \\
\hline 7 & PCJ Method (1996) & 2088 \\
\hline
\end{tabular}

Table 4: Comparison of flood discharge with various ungauged catchment methods.

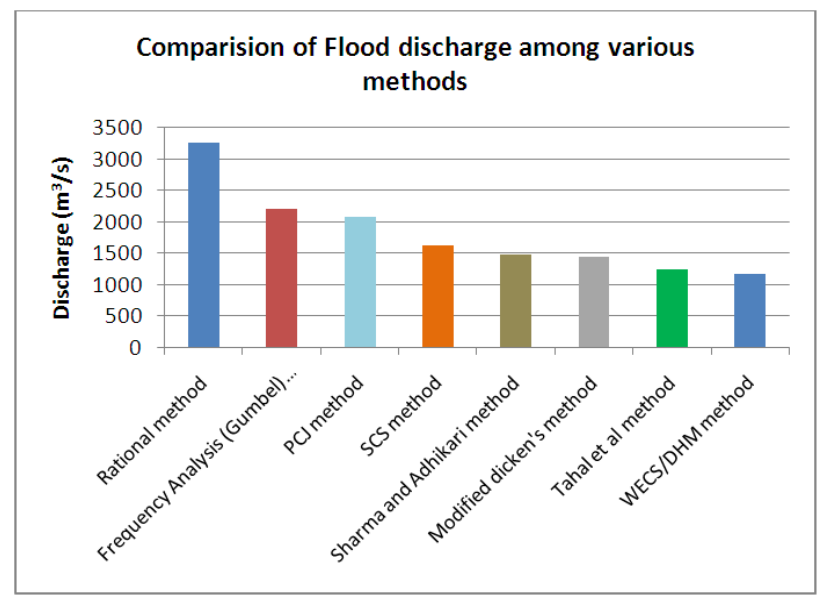

Figure 3: Comparison of 50 year Flood discharge at Rajaiya with various methods

\section{Conclusion}

Despite of existence of numerous methods of flood forecasting, further research on basin specific study still highly deserves. Rainfall run-off correlation is a widely used method for flood forecasting. However, the rainfall stations established in Nepal are far fewer in number than what the World Meteorological Organization (WMO) recommends. Furthermore, Chalise (1994) has argued that available data in Nepal may not always be reliable anyway. Nepal also lacks sufficient databases of hydrological and topographical characteristics that affect rainfall runoff data collection: land use, land cover, soil type, and fine resolution DEMs. Despite the obvious need to develop indigenous capabilities to carry out research at the national level and to generate a robust and long term database for developing hydrologic models for the Himalayan rivers, this standard of hydro-meteorological research has not yet been achieved in Nepal (Chalise, 1994). For these reasons, when designing flood control structures, Nepal relies heavily on ungauged river basin methods, which tend to be less accurate. The purpose of this paper was to see which ungauged method compared most favorably with gauged methods (Gumbel's or Log 
Pearson) to provide more accurate data to better inform flood structure design.

Among seven methods of flood forecasting used in this study, only the rational method yielded higher discharge value than that rendered through time series analysis of actual gauged data. The WECS/DHM method resulted in the lowest flood value followed by Tahal et al. (2002) method. Among these methods, PCJ (1996) method yielded the most comparable result with the gauged basin method. However, it couldn't be generalized that PCJ method would always provide comparable results with gauged basin methods; more case study work is needed in this regard as different basins will have temporal variations of hydro climatic parameters related to the effects of climate change.

The need for a more robust and long-term database on precipitation, runoff, erosion, sedimentation and land use changes for a better understanding of the impacts of human activities and natural (mainly hydroclimatic) process in the Hindu Kush Himalayan river basins has been well recognized (Ives and Messerli 1989). However, policy makers have yet to assign the proper resources to achieve this standard. It's high time to concentrate upon such issues to address the safety against flood hazards and disasters.

Krishna Prasad Rijal, holds a master degree (MSc) in Water Resources Engineering from Tribhuvan University, Nepal. At present, he is working as a Senior Divisional Engineer in Central Regional Irrigation Directorate under the Department of Irrigation, Government of Nepal since 2006. He has 12 years of experiences in Civil Engineering profession, especially in hydro sector. He is interested in research studies and training including project monitoring and evaluation, technical designs. He is the visiting faculty in National College of Engineering, Lalitpur, Nepal.

Corresponding address: krishnarijal@gmail.com

\section{References}

Chalise, S.R., 1994, High mountain hydrology in changing climates: perspectives form the Hindu Kush Himalayas.

DOI, 2006.Guidelines for irrigation systems design in hills and valleys, Full Bright Consultancy Pvt. Ltd. and Project Engineering Consultancy and Research Pvt. Ltd. (JV).

Garge, S.K., 2001. Irrigation Engineering and Hydraulic Structures. Khanna Publishers, Delhi.

Jacob, B.S., 1995. Hill Irrigation Engineering with special emphasis on Planning, design and implementation of farmer hill systems. IOE Pulchowk campus, TU, Kathmandu Nepal and The Ford Foundation, New Delhi, India.

Rijal, K.P., 2012.EastRapti River Training with PEP perspective. DWIDP bulletin, 2012, Pulchowk, Lalitpur, Nepal

Sharma, K. P, and Adhikari, N.R., 2004. Hydrological Estimations in Nepal. DHM, GON, Nepal.

Shilpakar, R.L., 2003, Geo-information procedures for water accounting: A case of the East Rapti River Basin, Nepal, an unpublished M.Sc. thesis submitted to International Institute for Geo information Science and Earth Observation, ITC, Enschede, The Netherlands.

Subramanya, K., 2004. Engineering Hydrology (Second Edition), TATA McGRAW Hill, New Delhi.

Jha, P. C., 1996, Maximum storm design flood for road structures of Nepal, a Ph.D. Dissertation, Moscow.

Note: Basin specific data in this paper are abstracted from Sharma and Adhikari (2004) and Shilpakar (2003).

\section{CALENDER OF EVENT-HYDROPOWER}

November, 2014: 7th International Conference Small Hydropower Plants in Romania. Location: Exporom- Bucharest, Contact: info@reeco.ro
11-13 November, 2014: Hydro vision Brazil. Location: Sao Paulo, Brazil. URL: http//www.hydrovisionbrasil. com

\section{RENEWABLE ENERGY}

03-05 September, 2014: Renewable Energy India Expo, Location: Greater Noida, India. Organizers: UBM India. Email: rajneesh.khattar@umb.com URL: www.renewableenrgyindiaexpo.com

09-10- February, 2015: 4th Annual International Conference on Sustainable Energy and Environmental Science (SEES 2015). Location: Singapore. URL: http://www.env-energy.org/

9-11 December, 2014: Power Generation Week. Location: Orange Country Convention Centre, Orlando, FL, USA. URL: www.powergenerationweek.com

9-10 September, 2014: 3rd Annual Chilean International Renewable Energy Congress. Location: Santiago,
Chile. Email: info@greenpowerconferences.com URL: http://www.greenpowerconferences.com/ home/allevents

23-24 October, 2014: Solar Indaba. Location: Sandton Convention Centre Johannesburg, South Africa. Email: info@greenpowerconferences.com URL: http://www.greenpowerconferences.com/home/ allevents

24-26 September, 2014: World Bio Markets Brasil. Location: Sai Pauli, Brasil. Email: info@ greenpowerconferences.com URL: http://www. greenpowerconferences.com/home/allevents 4-5 February, 2015: 7th Annual SPG USA'15 Solar Power 